\title{
PREFACE TO THE 1968 PRINTING
}

I originally undertook the study reported in this book because I thought I would be able to observe the transformation of a group of automobile assembly line workers (and their families) into the "suburbanites" who had become stock figures in American popular culture in the 1950's through the satirical and straight efforts of a variety of popular magazines. It seemed to me that, having found a working-class population more than two years settled in a new suburb, I was provided with an almost natural experimental setting in which to document the processes through which "suburbia" was supposed to exercise its profound and diffuse influence in transforming a group of mostly poorly educated and semi-skilled factory workers into those model middle class Americans obsessed with the problems of crabgrass and "conformity."

Well, it is now a matter of public record that my basic assumption was wrong. As the interview evidence piled up, it became clear that the lives of the suburbanites I was studying had not been profoundly affected in any statistically identifiable or sociologically interesting way. But I was cautious in the general inferences I drew. (While writing the book I remember the sign I put on the wall over my desk; it read: "Remember: ritual caution.") The study was based on only one small sample, of one suburb, of one metropolitan area, in one region, and it suffered from all of the methodological limitations inherent in small case studies. Its results were sufficiently clear, however, to enable me to question the right of others to generalize freely about "suburbia" on the basis of very few studies of selected suburbs which happened to be homogeneously middle or upper middle class in character -especially when it seemed apparent that suburban housing was increasingly available to all but the lowest income levels and status groups.

The research that has been done on suburbs in the years since 
I did my own has given me no reason to alter the conclusions I drew then; it has, in fact, strengthened them. Samuel Kaplan helped enormously by undertaking in 1964 a replication of my own study, which largely confirmed its major findings. But in addition to Kaplan's work, we now have access to S. D. Clark's survey of a variety of suburbs around Toronto and Herbert Gans' monumental study of predominantly lower-middle-class Levittown, New Jersey, as well as to smaller studies, for example, Scott Greer's study of a Negro suburb of St. Louis, Walter's and Wirt's study of Cleveland suburbs, and the studies of William Dobriner and John Liell of Levittown, New York-Liell's work being the first I know of to study a suburb over a substantial period of time, first in 1951, shortly after its founding, and again in 1960 . Now, the big survey research centers are going beyond case studies to generalizations about suburbia based upon the study of national samples of population analyzed in terms of place of residence. ${ }^{2}$

None of this research can be expected to give much comfort to those who find it convenient to believe that living in suburbs exercises some mysterious power over its residents to transform them into replicas of Whyte's practitioners of "The Outgoing Life." There seems to be increasing consensus among students of suburbs that suburban development is simply the latest phase of a process of urban growth that has been going on for a long time, that the cultural character of suburbs varies widely in terms of the social make-up of its residents, and the personal and group

\footnotetext{
1 See Samuel Kaplan, The Auto Worker in Suburbia, A Replication of WorkingClass Suburb, M.A. thesis, University of California, Berkeley, Department of Sociology, 1965; Herbert Gans, The Levittowners (New York: Pantheon Books, 1967); S.D. Clark, The Suburban Society (Toronto: University of Toronto Press, 1866); William Dobriner, Class in Suburbia (Englewood Cliffs, N.J.: PrenticeHall, 1963). See also Scott Greer and Shigeo Nohara, "Suburb or Shacktown, the Portrait of an All Negro Community," John Liell, "Social Relationships in a Changing Suburb, A Restudy of Levittown," and Joseph Zelan, "Intellectual Attitudes and Suburban Residence," papers delivered at the 1963 meetings of the American Sociological Association. See also Benjamin Walter and Fred Wirt, "Political Competition in American Suburbs," delivered at the 1968 meetings of the A.S.A. It might be noted here that although the subtitle of the work by John Seeley, et al., is A Study of the Culture of Suburban Life, the housing development examined is not actually a "suburb," as that term is used in this book. It is located well within the city of Toronto itself.
} 
dispositions that led them to move to suburbs in the first place; that the variety of physical and demographic differences between cities and suburbs (and there are some) bears little significance for the way of life of their inhabitants, and that some of these differences, although statistically accurate, are sociologically spurious, since the appropriate comparisons are not between residential suburbs and cities as wholes, but between suburbs and urban residential neighborhoods. The high degree of order that was asserted as characteristic of suburbia was a result of highly ordered suburbs having been selected for study, and in general the reported changes in the lives of suburbanites were not caused by the move to suburbia, but were reasons for moving there in the first place.

In suburbs, as in city apartments, the degree of sociability is determined not primarily by ecological location but by the homogeneity of the population (although as Whyte indicated, the particular flow patterns of sociability may be affected by the specific locations of domiciles). Social class, the age-composition of residents, the age of the neighborhood are much more profound predictors of style of life than is residential location with respect to city limits. Transient attitudes (if they were there to begin with) apparently decline with the increasing age of the suburb, as the neighborhood settles into the style of life determined largely by its dominant social and demographic characteristics, a settling simplified by the economic homogeneity of specific suburban housing tracts. Analysis of national samples has provided confirmation neither of a Republican trend in politics nor a return to religion.

It seems, then, that there are no grounds for believing that suburbia has created a distinctive style of life or a new social character for Americans. Yet what I called "the myth of suburbia" persists, as is evident from the fact that "suburbia" is still very serviceable in public discourse as a highly evocative symbol, and is still eminently discussable over the whole range of our cultural media, from comic books to learned journals. One should not be surprised at this, for myths are seldom dispelled by research; they have something considerably more powerful than mere evidence going for them. And though nothing I say here can change this 
fact (for knowledge is not power), it is important for us to understand the power of the myth and the nature of its appeal to America's image of itself.

In the final chapter of the book, I undertook a functional explanation of the myth of suburbia: suburbs were rich with visible symbols readily organizable into an image of a way of life which could be marketed to the non-suburban public. The marketing was facilitated by the fact that the myth of suburbia conveniently suited the ideological purposes of several influential groups skilled in the marketing of a variety of social and political opinion. The descriptive accuracy of the myth of suburbia went largely unchallenged because it suited the prescriptive desires of opinion groups ranging from the yea sayers of the right through the agonizers of the center to the nay sayers of the left.

But though I think this analysis still makes good sense, I think too that there is something more, which I was only dimly aware of then. "Suburbia," I wrote, "is America in its drip-dry Sunday clothes, standing before the bar of history, fulfilled, waiting for its judgement." I suspect now that when I wrote this I was less interested in understanding the full significance of what I felt to be true than I was in simply turning a fancy phrase. But I think now that the notion that Suburbia is America is the most recent of our society's periodic attempts to come to terms with the melting pot problem, a problem that goes straight to the heart of the American ambivalence about cultural pluralism.

America has never really come to terms with the legend of the melting pot. That legend, if I may quote the windy text of its original source, saw America as the place where "Celt and Latin, Slav and Teuton, Greek and Syrian, Black and Yellow, Jew and Gentile, the palm and the pine, the pole and the equator, the crescent and the cross" would together build "the Republic of Man and the Kingdom of God."2 Despite the hope that a unified American culture might emerge from the seething cauldron, it didn't happen; instead, the formation of ethnically homogeneous communities-ghettoes-helped the immigrants preserve large segments of their cultures, and the tendency to endogamy

\footnotetext{
${ }^{2}$ Israel Zangwill, The Melting Pot (New York: The Macmillan Co., 1009).
} 
helped them preserve it beyond the first generation. But in spite of the evident facts of our cultural pluralism (by which I mean the persisting correlation of significant differences in values and behavior with ethnic, regional, and social class differences), attempts are continually made to create an image of the typical or representative or genuine American and his community, attempts which have usually succeeded only in creating stereotypes-most familiarly, perhaps, a caricature of one or another variety of Our Town: white, Anglo-Saxon, Protestant, and middle class. Saturday Evening Post covers, white picket fences, colonial houses, maple hutches, and such have historically played an important role in such attempts. The myth of suburbia is the latest attempt to render America in this homogeneous manner, to see in the highly visible and proliferating suburban developments a new melting pot which would receive the diverse elements of a new generation from a society fragmented by class, region, religion, and ethnicity, and from them create the American style of life. Suburbia as America is no falser a picture, probably, than Babbitt or Our Town as America but it fails as a melting pot for the same reason that the original melting pot idea failed: like many other urban neighborhoods, specific suburbs developed a tendency to homogeneity, almost always in terms of social class and very often in terms of ethnicity.

The myth of American cultural homogeneity and the facts of heterogeneity reflect a persistent ambivalence in American society regarding cultural unity and diversity, between the melting pot idea and the pluralist idea. During and after the period of rapid immigration into the "teeming cities," for example, free public education expressed the need for some minimum "Americanization" whereas the ghetto expressed the impulse to cultural self-preservation (both by the natives who excluded and the immigrants who segregated themselves). Fourth of July style patriotic rhetoric expressed the gropings toward an elementary national identity whereas provincial arrogance, and hostility to "the government" and to centers of cosmopolitan influence expressed the affirmation of narrow local autonomies. The ambivalence was really a double ambivalence; each polar position was itself unstable: to be truly tenable, a pluralist ideology must 
accord intrinsic honor and value to a diversity of life styles, and this it has never completely done; the salient features of minority subcultural styles have more often than not been regarded as stigmata by dominant groups, tolerable so long as they were temporary, that is, transitional to something approaching the dominant cultural style. On the other hand, the attempts of provincial, nativist, ("WASP") groups to secure their own style as the American style stopped short of supporting the emergence of broadly inclusive national institutions which would have facilitated that transition. The most enthusiastic celebrators of "Americanism" were precisely the groups who were most wary of integrating the varieties of the national life into a unified culture.

Indeed, a unified national culture has until quite recently been a most improbable prospect since the United States has traditionally been a society without very powerful national institutions to promote that unity and pass it down the generations. Without an established church or a powerful federal government, without national political parties or a standardized educational system, enormous distances and poor communications enabled local economies to breed a highly differentiated system of native subcultures-in addition to those created by the immigrants. Even today, there are probably dozens of distinctive American types, to some extent stereotypes, perhaps, but which nevertheless call attention to the wide variety of native styles: Vermont farmers and Boston Brahmins, Southern Bourbons and Tennessee hillbillies, Beatniks and organization men, Plainvillers, Middletowners, and cosmopolitan intellectuals, to say nothing of teenagers, the jet set, and many, many more, all American, all different, and none probably very eager to be integrated into a conceptualization of "American" at a level of complexity suitable for a Time cover story or a patriotic war movie.

It is not surprising, then, that when one tries to abstract from American life a system of values which can be called distinctively or representatively American, the task is immensely difficult. The most systematic attempt by a sociologist, that of Robin Williams in his book American Society, ${ }^{3}$ is foiled by the fact that

\footnotetext{
${ }^{3}$ Robin Williams, American Society (New York: Alfred A. Knopf, 1961); see chap. $x i$.
} 
important groups in American society do not share the 15 or 16 values which he offers as basically American. There is no question that values such as "achievement," "work," "efficiency," "equality," and the rest have played an important part in creating the quality of American life, but important parts of the lower and working classes (important because of their numbers) do not share them, and important parts of the upper class (important because of their influence) do not share them. The very poor are different from you and me, and (as Scott Fitzgerald is said to have remarked to Ernest Hemingway) so are the very rich.

The persistence of the myth of suburbia, then, reveals a continuing tension in American society between the ideals of cultural diversity, and the persistent attempts to find some transcendent principles or values which define the unity of American culture have been compromised by the persistence of important class and ethnic differences. Even under natural or "organic" conditions "American" patterns of culture are enormously difficult to describe with salutary accuracy. This difficulty is exacerbated when a society becomes sophisticated enough to be self-conscious about its culture and rich enough to do something about it. The maturity and the luxury of our civilization constrain its elites to define an "American" style, and the miracle of our technology arms us to manufacture it. Our society is wealthy enough to support a substantial class of intellectuals devoted to staying on top of contemporary events to "spot the trend," "see the pattern," "find the meaning," or "discover the style." And our media are such that these spottings and seeings are more or less instantaneously communicated to audiences of millions, whose demand upon the marketers of opinions and interpretations for sensible and coherent syntheses is greater than the available supply.

Under such conditions, we do not get serious historical interpretation of contemporary events; we do not even get responsible journalism; we get myths, which themselves become part of the forces shaping what is happening, and which hence function ideologically. The myth of suburbia fosters an image of a homogeneous and classless America without a trace of ethnicity but fully equipped for happiness by the marvelous productivity of 
American industry: the ranch house with the occupied two-car garage, the refrigerator and freezer, the washer and dryer, the garbage disposal and the built-in range and dishwasher, the color TV and the hi-fi stereo. Suburbia: its lawns trim, its driveways clean, its children happy on its curving streets and in its pastel schools. Suburbia, California style, is America.

Most American intellectuals have found this image repugnant, but the bases of their antipathy have never really been made clear. Somehow associated with these physical symbols of suburbia in the minds of most intellectuals are complacency, smugness, conformity, status anxiety, and all the rest of the by-nowfamiliar and dreary catalogue of suburban culture. But the casual connection between the physical character and the alleged cultural style of suburbia has never been clearly established. It is almost as if American intellectuals felt, consistent with Puritan tradition, that physical comfort necessarily meant intellectual sloth. Perhaps it is because we have been too well trained to believe that there is somehow a direct relationship between the physical structure or the esthetic shape of a residential environment and the sort of values and culture it can possibly engender -so that the esthetic monotony of suburbia could house nothing but a generation of dull, monotonous people, and its cheerful poverty of architectural design could breed nothing but a race of happy robots. The only trouble with this view is that there is little evidence and less logic to support it. Most of the adult suburbanites were urban bred, and hence presumably already shaped by the time they became suburbanites. And although it is still a little too early to tell what kind of culture will be produced by the generation bred in the manufactured environment of suburbia, we might remember that most of the critics of suburbia were bred in the manufactured environment of New York and other big cities.

But becoming aware of the myth of suburbia, and pointing to the disparities between it and what we actually know of suburbs we have closely studied, should not be confused with a defense of suburbia. Nor should anything I have said about the critics of suburbia be interpreted as a revelation of my personal bias in favor of suburbia. As I suggested earlier, myths are potent 
enough to survive evidence; they are not disarmed by understanding. Quite the contrary. Once myths gain currency, once they go, as we say, "into the cultural air," they become real, and function frequently as self-fulfilling prophecies. Life copies literature; fact is affected by fiction; history is constrained by myth. "If a situation is defined as real," said William I. Thomas, "it is real in its consequences," and I have no doubt that family decisions regarding whether to move to the suburbs have been affected (both pro and con) by the myth of suburbia. And despite everything reasonable I have said about suburbs, I know that the fact that I unreasonably dislike them has been conditioned, beyond the possibility of redemption by mere research, by the fact that the myth of suburbia exists.

B.B.

Davis, California

January, 1968 